\title{
The Spirituality of the Women Body in Galih Reza Suseno's Paintings
}

\author{
Nanang Yulianto ${ }^{1}$, Narsen Afatara ${ }^{2}$, Bani Sudardi ${ }^{3}$, and Warto ${ }^{4}$ \\ $\left\{\right.$ nanangfirel@yahoo.co.id $\left.{ }^{1}\right\}$ \\ 1,2,3,4 Universitas Sebelas Maret, Surakarta, Indonesia
}

\begin{abstract}
Abstarct. This research aim is to analyse the various images of women body in Galih Reza Suseno's paintings in a spirituality perspective. This research was conducted at Galih's painting studio located in JetakMredoRt 3/ Rw 1 Bangunharjo, Sewon, Bantul in September - December 2018 using a descriptive qualitative research method. The research strategy used is anembedded single case study. Furthermore, the sources of data are consisting of informants, places and events, archives/ documents. The sampling technique used is purposive sampling technique. The data are collected using observation, in-depth interviews, document/ content analysis. The data are validate using source triangulation, informants review. Furthermore, the data are analysed using an interactive model consisting of data reduction, data presentation, and drawing a conclusion. The result shows that the women's image presented by Galih was a gentle, calm, peaceful, and optimistic women which is always revealing every reality of life that existed in responding toward life. Thus, it is to find the spirituality values as the essential values of life.
\end{abstract}

Keyword: image, women body, painting, spirituality

\section{INTRODUCTION}

Culture shows a dynamic development. Recently there is a movement called new age (zaman baru) as a critical reaction for a rational modern culture in order to find the balance ratio and faith [1]. People are associated the new age with the reviving phenomenon or the increasing people's tendency toward spirituality. When the society's frame of life is centred on religion and the sanctity rite of life, the body is celebrated in a sacred and respected aesthetic [2]. The symbolism of body is united as a microcosm with the macrocosm as a conception, nurse and the continuation of life. This exposure is a representation of cultural practices that occur recently.

The practices of visual culture especially painting is related with the subject matter of a women body that shows there is a visual diversity. The women body is an important part of the painting practices both in Indonesia and abroad. Women are the most interesting subject matter in the entire century of an art development in the world [3]. The womenare tempting to be expressed in various forms of arts. Women are complex creatures and contain many mysteries.

The mysteriousness of women is as an attraction and a source of inspiration for painters. Galih Reza Suseno is one of the painters who was quite intense in expressing women's bodies in his paintings with various images. Galih tried to express the spirituality values through the women body in his paintings. Spirituality as a process of finding the meanings, purposes, 
moralities, prosperities in a relationship with oneself, others, and ultimate realities. People can express spirituality in religious or non-religious terms [4].

The expression of women's body in Galih's paintings is a spiritual emanation that present in his soul. Galih states that painting for him is a medium to express various values of life that lies behind a woman's body. There are life spiritualties in women's bodies. The women's body are considered as a life energy and a source of spirituality during the creation of painting made by Galih Reza Suseno.

\section{METHOD}

This research was conducted at Galih Reza Suseno painting's studio in Jetak Mredo RT 3/ RW 1 Bangunharjo, Sewon, Bantul in 2018 of september - december. This research employs descriptive qualitative method. The descriptive research is intended to understand the phenomenon of what is experienced by the research subjects, hollistically, and decribed in form of words and languages, in a certain natural context by utilizing various natural methods [5]. The research strategy used is an embedded single case study. An embedded research as a step before conducting research in which the researcher must choose and determine the variables that become the main focus but remain open with the character of interactive and flexible [6].

The source of data of this research are comes from informants, places and events, archives/ documents. The sampling technique used is a purposive sampling technique. The data were collected using observations, in-depth interviews, archives/ content analysis. Furthermore, the data were validated using source triangulation, informants review. Data analysis using an interactive model consisting of data reduction, data presentation, and drawing a conclusion. The stages of frameworks are as follows:

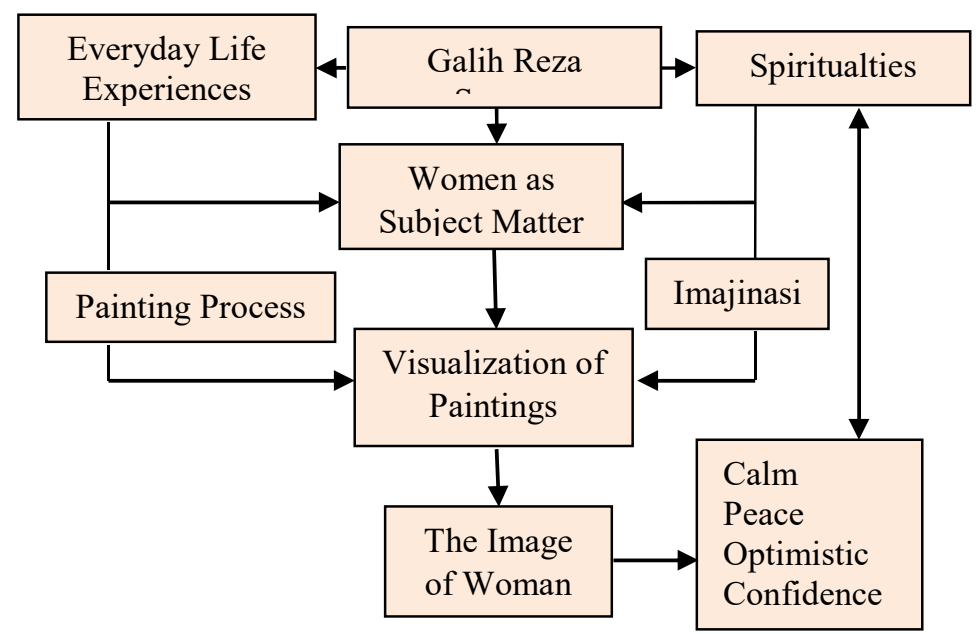

Scheme 1. Research Problem Solving

\section{RESULT AND DISCUSSION}

\subsection{Galih's Painting with Spirituality can be Identified as Follows:}

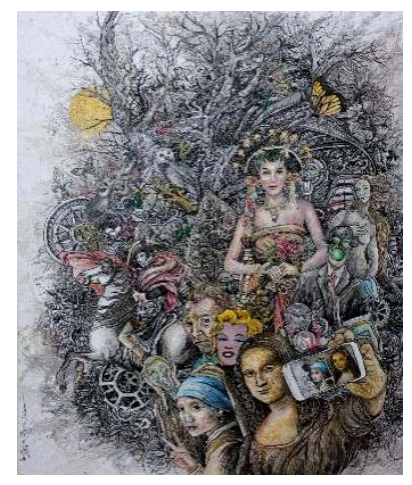


Fig. 1.Menemukanmu Dalam Rimba Fana, Acrilic in kanvas, 170x140 cm, 2016

Picture number 1 tell us about the painting visualization in the form of a woman using Javanese bridal clothing among popular women with a background of a jungle wilderness. That painting represents the search for Indonesian identity which is faced with the temptation of unlimited media and information causing people to just know about the surface without understanding anything. How far the effort to portray our westernized self, however we certainly miss the Indonesian culture. Galih was fascinated with foreign women, however when choosing his life companion he would still choose Javanese women.

The image of women presented is a woman who is gentle, confident, brave, and calm. Those images were expressed through the expression of clear and sharp eyes staring forward which is inscribe a strong sense of confidence in determining her way of life. Both her hands hold a flower represent the loyalty to the love and affection that God bestowed on her. The natural body gestures without any tense inscribe the softness and calmness in her soul.

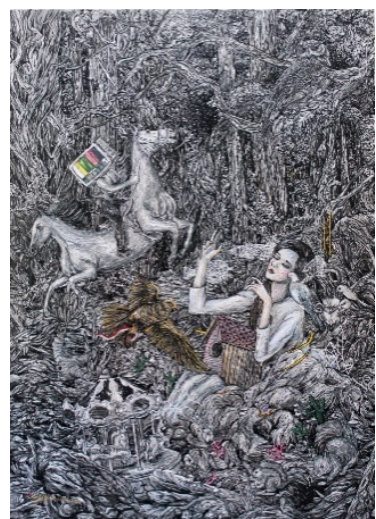

Fig. 2. Nyanyian Sunyi Seorang Bisu, Acrilic in Kanvas, 90x140 cm, 2017

The picture number 2 is the painting visualization of a woman in a dense forest, around her there are a horse that has 2 heads ridden by television-headed men, perched and flying birds, rabbits and other animal houses. That painting represent woman who is secluded into the forest as to be able to sing with the nature. She realized that even in the darkest place she remained helpless. On herself there is a house that remained in her lap, a physical house and a soul house. She did not want to be swayed by the flow of misleading media. The Garuda is about to anchored, residing in her heart that is surrounded by a sense of calm and peace. 
The image of woman presented is in the form of a peaceful, calm and optimistic woman. That image is strengthened with her facial expression that look up with eyes closed tightly as a form of expression while enjoying the familiarity of the nature as a home for her body. She is communicating with the nature using her feelings. Self-optimism in finding happiness though her exile from the modern world which alienates her body from the universe. In natural caresses she found her calm and peace.

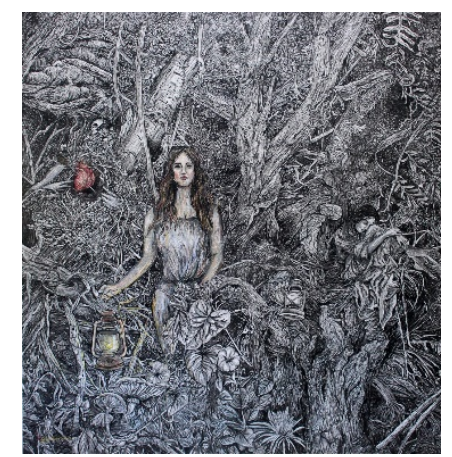

Fig. 3. Aletheia, Akrilik in Kanvas, 150x140 cm, 2017

The picture number 3 is about the painting visualization of a woman carrying a lamp lit in the darkness. In the background there is a woman who is sitting down between the trees and the blossoming flowers. The painting represents about the meaning of truth that can be found through revelation so that nothing is hidden. Human are always disclosing each reality in order to find an understanding so that they find the true way of life, known as serenity and peacefulness of life. The image of women presented are the patient, confident, calm and optimistic women. It is presented through a cheerful facial expression and a sharp look at the front. Bright light always unites with an aura of oneself that is confident, optimistic in illuminating the path of life.

The various images of women presented in Galih's paintings considered women body as the medium to interpret spirituality in the context of modern life. Galih's painting raised his longing and reflection on the natural atmosphere [7]. He wants to feel the calm atmosphere again. Galih depicts natural and organic forests as imagined by the believed God.

Through his painting, Galih is always wants to lead to the issue of the human life spirituality. The women body cannot be separated with the nature which provides tranquil, peace, warmth, and calm as a united force to discover the Divine values. Women's bodies are always constructed so that they can emit a calm, peaceful, gentle, confident and optimistic self-image. The women's bodies portrayed by Galih are soft but strong, calm but optimistic bodies, able to nourish arid souls because they are caught up in the flow of modern culture that prioritizes physical things.

In the eco-feminism perspective, the women's bodies in Galih's paintings are expected to be a saviour for the natural ecosystems sustainability. Eco-feminism will show the role of women who are more close to the nature, besides being positioned as the victims as well as women also positioned as the saviour for themselves and the future of the natural ecosystem (world) [8]. The presence of nature and humans is a balance that will draw closer to the One/ Almighty [9]. Let the nature talk to us through bird whistles, raindrops, rustling of leaves in the 
wind, and silent voices. Feel the peace and calm that spreads in your heart, let the mind rest for a moment. Feel that nature is a part of yourself.

Galih's paintings rests on the idea of embracing God in life, through an autocratic path to the world of images that co-opt with everyday life, including in religious practices [10]. Galih find it through the path of art that is spiritually charged, art that can perceive the values of life spirituality as a form of trust in the existence of God.

Based on the various descriptions mentioned before, it is increasingly emphasized that Galih is always wants his painting to be able to build awareness of the importance of spirituality in modern life. The women body exposed in the painting become an important subject, thus the women's bodies in the modern culture atmosphere tends to be the object of exploitation. However, in Galih's paintings it is placed as a subject that can balance the nature in order to achieve the life spirituality values.

\section{CONCLUSION}

Galih's painting of a woman's body are based on the concept of life spirituality. The visualization of the women's body portrays calmness, tranquillity, silence, peace, confidence, optimism as part of life's spirituality. The women's bodies that dare to choose the path of life are friendly with the nature as an effort to be always communicate with the God. The women's bodies that can arouse a space of awareness of the importance of life balance between the material and spiritual, as a unity that cannot be separated in order to find the meaning of the essential life.

\section{REFFERENCES}

[1] Rahmatiah, Sitti. Perkembangan Aliran Spiritualisme Di Dunia Islam. Sulesana Jurnal Wawasan Keislaman UIN Allaudin Makasar Volume 12 Nomor 1. 2018.

[2] Soetrisno, Mudji. Estetika Tubuh Dalam Oase Estetis, Estetika Dalam Kata dan Sketza. Yogyakarta: Kanisius. 2006.

[3] Djien, Oei Hong. Misteri Perempuan Tiada Habisnya Dalam Kumpulan Tulisan dr. Oei Hong Djien: Seni dan Mengoleksi Seni. Jakarta: Gramedia. 2012.

[4] Amir,Yulmaida. Religiusitas dan Spiritualitas: Konsep Yang Sama Atau Berbeda? Jurnal Ilmiah Penelitian Psikologi: Kajian Empiris \& Non-Empiris Vol.2, No.2. 2016.

[5] Moleong, Lexy. Metodologi Penelitian Kualitatif. Bandung: Remaja Rosdakarya. 2010.

[6] Sutopo. Metodologi Penelitian Kualitatif. Surakarta: Universitas Sebelas Maret. 2002.

[7] Marianto, Dwi. Salam Alami. Katalog Pameran Tunggal Imago Dei Di Bentara Budaya Yogyakarta 21-28 Juni 2017.

[8] Solichin, Moh. Badrus. Ketika Alam dan Perempuan Lembah Baliem Diperkosa oleh Antroposentrisme Kapitalis: Kajian Ekofeminisme dalam Novel Tanah Tabu. Semiotika: Jurnal Ilmu Sastra dan Linguistik Universitas Jember Vol.19 No.1 2018

[9] Kartikasari, Yasmin. Alam, Manusia, Dan Spiritualitas. Jurnal Sosioteknologi FSRD ITB Edisi 24, Desember 2011

[10] Wisetrotomo,Suwarno. Mencari Tuhan Dalam Keriuhan. Katalog Pameran Tunggal Imago Dei Di Bentara Budaya Yogyakarta 21-28 Juni 2017.

[11] Arivia, Gadis. Goddess, Ketubuhan dan Alam: Kajian Spiritualitas Ekofeminisme. Jurnal Perempuan Untuk Pencerahan dan Kesetaraan, Vol. 19 No. 1, Februari 2014 